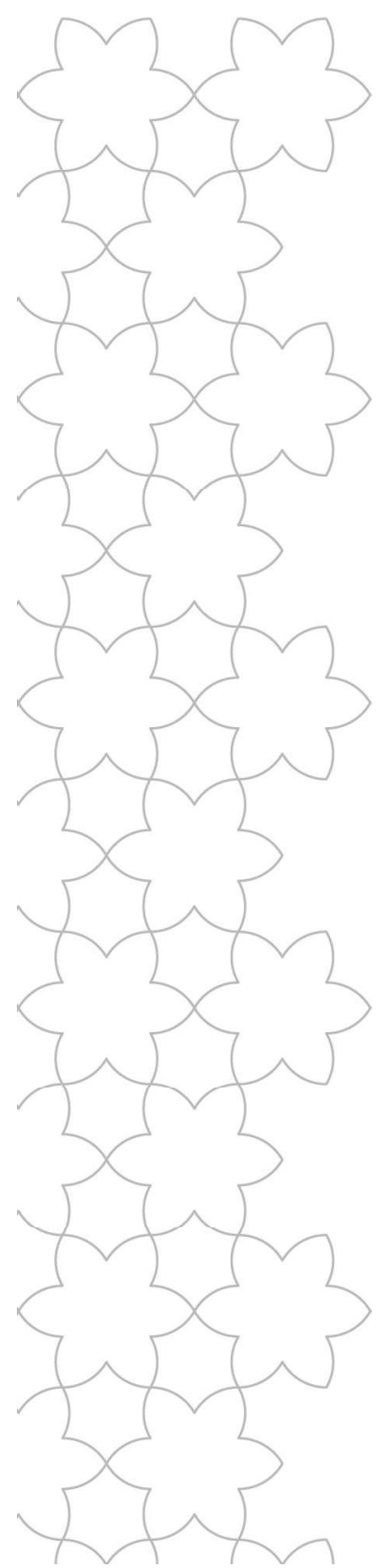

\title{
"LIFE IS A DREAM": IBN 'ARABĪ ON THE MYSTERIES OF DIVINE GINEMA
}

\section{James W. Morris (Boston College)}

\begin{abstract}
We are the bees of the invisible. Lovesick, we forage for the honey of the visible, to store it in the great golden hive of the Invisible.
\end{abstract}

Rainer Maria Rilke ${ }^{1}$

For Ibn 'Arabī, as for Plato and Dante (or Calderon), all of earthly life and existence is essentially a divine Dream: ${ }^{2}$ a singular, ongoing, timelessly interpenetrating, profoundly meaningful and ultimately transformative cinematic drama-that cosmic "Play" and universal shadow-theater whose personal meanings and mysteries each of us must gradually discover through all our hastily improvised roles as audience, author, reader, performer, and even critic. ${ }^{3}$

This essay, centering on key passages translated for the first time from the concluding volume of our Murcian master's immense book of Meccan Illuminations, highlights some of

1 Rilke, letter from 1925, shortly before his death (translated from the French original). The surrounding passage in that letter beautifully encompasses the fundamentals of Ibn 'Arabì's teachings presented below:

"We are continually overflowing toward those who preceded us, toward our origin, and toward those who seemingly come after us. ...It is our task to imprint this temporary, perishable earth into ourselves so deeply, so painfully and passionately, that its essence can rise again, invisibly, inside us. We are the bees of the invisible. We, lovesick and desperate, forage for the honey of the visible, to store it in the great golden hive of the Invisible. Transitoriness is everywhere plunging into a profound Being...The earth has no other refuge except to become invisible: in us, who, through one part of our nature, have a share in the Invisible.... Only in us can this enduring transformation of the visible into an invisible no longer dependent upon visibility and tangibility be accomplished, since our own destiny is continually growing at once more actual and invisible within us".

2 Throughout this essay, ruja has been consistently translated as "dream," but the term more broadly refers to all forms of "vision," including those in a waking or enlightened state. Equally importantly, it includes all forms of perception and both the spiritual and physical senses (i.e., everything that is perceptible in al-khayall, the divine "Imaging-forth" of all creation), and is in no way limited to our physical sight or sense of vision.

3 See the translation of chapter 317 afrom the Futūhāt and the extended discussion of that key passage in chapter 5 of The Reflective Heart: Discovering Spiritual Intelligence in Ibn 'Arabì's Meccan Illuminations (Louisville: Fons Vitae, 2005). 
the key elements of the universal process of spiritual realization within which each human being gradually moves from the perception of this unfolding shadow-play in sharply limited worldly terms toward the deepening recognition of its aim and fulfillment as a shared, neverending adventure of divine-human discovery. In order to provide a basic metaphysical framework for these more focused and practical insights, I have begun here with a few more familiar selections from Ibn 'Arabī's earlier foundational chapter (63) devoted to outlining our human relation to this entire Play of our earthly (and posthumous spiritual) existence conceived as a cosmic divine "Imagining" (hayāl) within which we and our familiar worlds are both the dreamed and yet also - in so many shifting ways - active dreamers.

Given the larger film festival context of this conference, ${ }^{4} \mathrm{I}$ had originally hoped to draw out more explicit connections at each stage between Ibn 'Arabī's teachings and observations and particular cinematic illustrations fitting each of these short passages. However, given both the greater time that would require and the need to clearly explain each of the chosen examples we might take up, I must ask each of you instead, as we proceed, simply to notice the pertinent illustrations that will inevitably come to mind. Ibn 'Arabī's typical writing procedure, throughout the prose sections of his Futühatt, is to alternate suddenly between relatively abstract and often paradoxical or mysterious metaphysical and scriptural exposition, on the one hand, and sudden imperative demands that his individual reader "Know!," "Ponder!," "Recognize!," or "Delve into the depths!" of their own experience in order to discover the essential truth and deeper reality of what he had been discursively elaborating. That distinctive rhetorical procedure quite intentionally lends itself to bringing out each reader's deeper, pre-reflective awareness of the relevant meanings and guidance that can only be discovered and consciously recognized from within his or her own lifedream.

As one rich and appropriately detailed exploration of this complementary relation between Ibn 'Arabī's metaphysical perspectives and much contemporary film-making, explained primarily with reference to the shorter and widely accessible Fusūs al-hikam, I can at least refer readers now to a recent pioneering and highly suggestive study of Christopher Nolan's Inception by one of our doctoral students. ${ }^{5}$

4 IBAFF (Ibn Arabi Film Festival), Murcia, and the Muhyiddin Ibn Arabi Society-Latina, III International Symposium Ibn Arabi of Murcia: Inspired reason and the path of the heart..., March 7-9, 2014.

5 Ogunnaike, Oludamini (2013) "Inception and Ibn 'Arabī," in Fournal of Religion \& Film, Vol. 17: Issue 2, Article 10. At: http://digitalcommons.unomaha.edu/jrf/voll7/iss2/10. 


\section{EXISTENGE AS DIVINE IMAGINING: THE UNIVERSAL "BARZAH" ${ }^{\circ}$}

Building upon earlier Islamic spiritual and metaphysical traditions, Ibn 'Arabī applies the rare Qur'anic expression "barzah" (originally the liminal "boundary" between two disparate forms or realities, as between shadow and light, or fresh and salt water) to symbolize all the immense realms and dimensions of creation and formal divine manifestation, beyond the purely noetic or intelligible dimension of the "First Intellect" ("Pen," etc.). These "intermediate" realms of formal manifestation and creation are often discussed - as in our selected passages below - in terms of a progressive series of "levels" (manāzil), domains of divine "Presences" (hadarāt), or "planes of emergence" and formal existence $\left(n a s^{2} a\right)$. And the analysis of those initial distinctions from cosmogonic, ontological, epistemological and eschatological perspectives was elaborately developed by centuries of subsequent commentators, critics, philosophers and scholastic theologians, particularly throughout the eastern Muslim world, in contexts and by authors that have been extensively studied in recent decades. ${ }^{7}$

For our limited purposes here, one of the classical summaries of Ibn 'Arabî's understanding of this barzah of the divine Imagination, focusing explicitly on its role in the phenomenology of spiritual experience-a perspective phrased here, as was commonly the case, in a familiar technical vocabulary drawn from Islamic eschatological conceptions and scriptures - is provided by chapter 63, one of the shorter summary chapters in the opening, foundational Section (fasl al-ma ärif, comprising chapters 1-73) of his Futūhāt. ${ }^{8}$ The following short selections from that chapter, adapted from an earlier, more complete translation and studies, should be sufficient to suggest some of the distinctive features of Ibn 'Arabì's complex understanding of the "dreamlike" character of those imaginal realities with which we are most familiar and within which we normally live our lives — while also highlighting

6 An earlier, more complete translation of this chapter, under the title Spiritual Imagination and the "Liminal" World: Ibn Arabi on the Barzakh, was published in POSTDATA (Murcia), vol. 15, no. 2 (1995), pp. 42-49 and 104-109 (Spanish). For a detailed and elaborately illustrated account of Ibn 'Arabî's larger cosmological and cosmogonic perspectives, see W. Chittick, The Self-Disclosure of God: Principles of Ibn al-'Arabi's Cosmology (Albany, SUNY Press, 1998, as well as the promised second volume of further cosmological translations and interpretation, and the earlier study in next note 7 below. Chapters 59-65 of the Futūhät focus schematically on the particular roles of human beings in that larger cosmological framework, largely expressed - as in our selections below - in the eschatological vocabulary of the Qur'an and hadith.

7 See W. Chittick, The Sufi Path of Knowledge: Ibn al-'Arabī's Metaphysics of Imagination (Albany, SUNY, 1989); the twenty translations, historical and interpretive studies (most previously published) collected in our forthcoming volume Approaching Ibn 'Arabi: Foundations, Contexts, Interpretations, and further recent studies in the extended bibliography of that work.

8 Vol. I, pp. 304-307; however this translation is based on the corresponding pages of O. Yahya's critical edition of this chapter. See n. 6 for the earlier, more complete translation and Spanish summary of this chapter. 
a number of the ways Ibn 'Arabī suggests that we are called to "wake up" and begin to recognize the deeper meanings and intentions embedded in this shared divine Imagining. Given the occasion of the Ibn 'Arabī Film Festival surrounding this text, it may also be helpful, for those in the audience encountering Ibn 'Arabi for the first time, to point out the many ways in which the metaphysics briefly outlined in the following abridged translation of chapter 63 closely corresponds to the problematic twofold nature of the Matrix introduced in the recent popular films of that name.

\section{Chapter 63: Concerning the Inner Knowing of the People's Remaining in the Barzah Between This-World and the Upraising (at the Day of Judgment)}

Between this low-world and the Rising, for the one who has spiritual vision, there are levels of the Barzah, each with their limits:

What they hold is according to the influence of how their possessor is today, before the deaths— so consider deeply [O people of vision] (59:2)!

They have influences and authority over everything, making the wonders appear: they do not spare anyone, nor leave anyone alone (74:28).

They have wide-open manifestations in being, without restriction, yet they are neither essential-realities, nor (mere) effects.

They (have only to) say to God "Be!," and He is creating them: so how can a mortal-human escape from their influence?!

Were it not for this (divine) Imagining, today we would be in nothingness: no goal or purpose would have been accomplished through us!

Now since the barzah (of the creative divine Imagination) is something separating what is knowable and unknowable, existent and non-existent, intelligible and unintelligible, affirmed and negated, it has been given the name "Barzah" as a technical term. It is intelligible in itself, yet it is nothing but the imagined-image (haya $\bar{l} l$ )! For when you perceive it - assuming you are in a rational state - you know that you have perceived something existent on which your gaze has fallen; indeed you most definitely know that there is absolutely something there. But what is this about which you affirm that it is an existent thing, while at the same time you are also denying that?! 
It is to something like this reality that each human being goes in their sleep and after their death (Qur'an 39:42). So that person sees (moral and spiritual) qualities and characteristics as self-subsistent forms that speak to him and with which he converses, as being bodies without any doubt. And the person of spiritual unveiling already sees (here), while they are awake, what the sleeper sees in their dream state or the dead person sees after they have died.

Now there are some people who perceive this imaged-object with the eye of the (physical) sensation, and there are others who perceive it with the eye of (divine) Imagining... So you should know with which eye you are seeing Him! ${ }^{9}$ For I have already let you know that (the divine) Imagining is perceived either through itself - I mean through the eye of imagination - or through the (physical) vision. And which of those two is the sound one on which we should rely?! Regarding that we (composed these verses):

When my Beloved appears to me, with which eye do I see Him?

With His eye, not with mine: for none sees Him but Him!

So wake up, you who are asleep and heedless of all this, and pay attention! I have opened up for you a door to forms of awareness and inner knowing that thoughts can never reach, though intellects can come to accept them.... Then the intellect accepts what the divine Self-manifestation (tağalli) gives it and knows that that (imaginal unveiling) is beyond its own power with respect to its thinking, indeed that its thinking could never give it that.... This is so that (such a person) may know that their receptivity (to what is uniquely revealed through this Imagining) is higher and more noble than their own discursive thinking. So realize from now on, o my brother, Who it is that is manifesting Himself to you from behind this door (of the creative Imagination)! For this is a prodigious matter, where even the innermost hearts become bewildered... And God says: So wherever you-all may turn, then there is the Face of God! (2:115) - and the "face" of something is its reality and its individual essence. So the (divine) Imaging-forth has given a form (of the cosmos in all its dimensions) to the One Who, according to the arguments of the intellect, cannot possibly be conceived or given any form. That is why (that divine Imagining) is so all-encompassing.

9 Throughout this section - as indeed whenever the key word 'ayn appears in such metaphysical contexts in any of Ibn 'Arabî's writings - he is usually playing with at least two of the many meanings of that Arabic word (which is also "source" and "wellspring"): i.e., with the eye as the organ of physical vision, and with the divine "essential reality," which is the manifested in the cosmic "Perfect/ Complete Human Being" (insān kämil and "Muhammadan Reality"), and which at the same time is the Source and wellspring of all the forms and degrees of human being, life, and perception. In short, the two "eyes" here allude to dramatically different realities and domains of experience and perception. The most succinct and influential summary of these key metaphysical and spiritual principles is found in the dense opening chapter (on Adam) of Ibn 'Arabï’s famous Fusūs al-hikam. 
As for this (Barzah) being made of "light," "10 that is because light is the immediate cause for (things) becoming unveiled and clearly appearing, since without light, vision would perceive nothing at all. So God makes this Imagining as a "Light" through which can be perceived the Bringing-into-form ${ }^{11}$ of every thing, whatever that might be, as His Light passes through the absolute nothingness so that He might shape it into the forms of being. Hence this Imagining is more deserving of the divine Name "the Light" (al-Nīr) than all the created things ordinarily described as "luminous," since Its Light does not resemble the (created) lights, and through It all the divine Self-manifestations/theophanies are perceived.

And $\mathrm{He}$ is the Light of the eye/essence of (divine) imagining (24:35), not the light of the eye of sensation. So understand this! For if you understand how that Imagining is Light, and you know in what way it is (always) correct, then you will have an advantage over those who don't know that - the sort of person who says: "that is only a false imagination!" That is because such people have failed to understand the perception of this light of imagination which has been given them by God.

So there is no doubt that the Presence (ontological domain) of the divine Actions and States [i.e., this cosmic barzakh of divine "Imagining"] is more extensive (than the higher, purely noetic divine "Presences"). That is why the true Knowers (of God) only find comprehensiveness of knowledge to the extent of what they come to know from the world. Then when they want to proceed to knowing the Unicity of God-may He be exalted!they keep on ascending gradually from that breadth (of worldly objects of knowing) toward what is narrower (in extent).

10 Alluding to a hadith, discussed in a passage of this chapter omitted here, that describes this reality as a "horn of Light." The following discussion likewise presupposes throughout the elaborate cosmic symbolism of God as "Light of the heavens and the earth..." set forth in the famous Light-verses of the Qur'an (24:35-44).

11 Taswer r, the active verbal form of "shaping creation", the expression of the divine Name of God as al-Musawerir, the "creative Shaper" or "Configurer" of all things. At the same time, this Arabic expression commonly refers to all the creative expressions of the arts that have their metaphysical "root" in that divine Reality/Name: i.e., painting, sculpture, architecture, cinema, literature, drama, and every other form of expressive "shaping." 


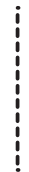

AWAKENING FROM THE DREAM OF THIS WORLD: THE GHALLENGES OF TRUE INTERPRETATION ${ }^{12}$

Within the wider Islamic tradition, and for Ibn 'Arabī in particular, the classical scriptural representation of the challenges of "seeing through" the dreamlike and initially chaotic events, actors, and occurrences of this world is provided by the figure of the prophet Joseph, since the Qur'anic account of his own testing, growth, and ultimate redemption of his brothers and family is phrased in an explicitly metaphysical symbolism that puts a particular emphasis on his inspired ability to perceive "the inner meaning of what happens" in this world ( $t a^{2} w \bar{\imath} l$ al-ahâadit $)$. Ibn 'Arabī's discussion of Joseph and his inspired spiritual insight into the dreamlike character of this lower world in his famous Fusūs al-hikam ("Bezels of Wisdom") has been summarized in several of the most important, pionecring studies of his thought, including the particularly clear and accessible related chapters in T. Izutsu's Sufism and Taoism: A Comparative Study. ${ }^{13}$

In the Futūhāt, one of Ibn 'Arabī's most succinct and straightforward presentation of these issues and insights is found in the penultimate chapter (559) of that work, which consists entirely of short, highly condensed accounts - combining poetry and rhymed prose (facilitating memorization) - of the central "inner secrets" or "essential meanings" (asrār) of all 560 chapters of this voluminous work. These short summary accounts are extremely useful not only for helping to understand the unifying ideas and intentions of what are often extremely lengthy and mysterious chapters, but also for introducing readers and students to more direct and accessible treatments of his foundational principles. Thus most of the following translated passages are drawn from that key summary chapter:

The people are only sleeping in this low world, so when they die, here is where they rise up. ${ }^{14}$

And what our eyes/selves are witnessing

is a dream appearing in our (earthly) slecp!

He [= Ibn 'Arabī explained: The human being in this lower life is in a dream. So because

12 This translated selection is from vol. IV, p. 434 of the many standard, "Bulaq"-based printings. Along with many of the translations below, it is drawn from the mysterious short summary descriptions in chapter 559 of the "inner secrets" of all 560 chapters of the work. Within these summaries, the word usually translated as "He explained..." below always refers to Ibn 'Arabî's own elaboration of these "inner mysteries" in the corresponding full chapters of the Futühät.

13 Berkeley, U. of California Press, 1984 (revised edition). Given the focus of Izutsu's study, his companion discussion of the "dream-like" nature of reality in Chuang-Tzu (Zhuangzi) provides a particularly illuminating background for this essay.

14 The underlying hadith is quoted soon after in the prose section translated below, and "rising up" here refers to the spiritual transformations of the "Rising" (qiy amma), which for Ibn 'Arabì is both an 
of that we are commanded ${ }^{15}$ to interpret/cross over (to its true meaning and lessons). (In the words of the famous Prophetic saying): "Ordinary people are sleeping, so when they die they wake up." Now since this was stated by the Truthful one (Muhammad), what is sensed is a (divine) Imagining, and what is sensible (for us) is (likewise divinely) imagined.

So what stops your trusting (in the reality of that saying) when you are the one repeating it? What breaks that (trust) is your mind's (deceptive) "knowing" that you are in a waking state, the sole master of your senses and what they are sensing.

So since you are sleeping, the Master of imagination and imagining, and the one (i.e., Muhammad) who received from Him the pathway to your ultimate happiness, has affirmed that you are (really) sleeping while you are in the state of the person who believes that you are the one who is wide-awake and alert in that state. But since you are in a dream in your waking state in this lower life, everything that you are experiencing here is something imagined and sought for something else — and it is not in itself in the way that you sec it.

Therefore the genuine sensing and wakefulness, with no illusory imagining in it, is in the plane of emergence (naša) of the other world. So don't say - if you realize the true nature of this - that miraculous occurrences ${ }^{16}$ are simply things "imagined" in the eyes of onlookers. Know that (instead) that the matter in itself is just as the eye sees it, and there is nothing hidden about what the eye witnesses: it is just what it is.

So understand! And following the Path depends on God... (16:9).

individual process (the "lesser Rising") and a universal, cosmic one (the "greater Rising").

15 Alluding to the Qur'anic verse 59:2, So draw out its lesson, you who possess (spiritual) vision! The Arabic root $\left({ }^{c} b-r\right)$ used here has the underlying meaning referring to the process and efforts of crossing over or traversing some distance, an emphasis that nicely conveys the many existential and personal factors involved in most efforts of spiritual understanding and discernment of a spiritual lesson ( $i b r a$, elements which are not readily conveyed by the usual intellectual connotations of the English word "interpretation."

16 The broad Arabic expression here (harq al- $\bar{a} d a)$ refers to anything perceived as somehow "going beyond the "habit" of the familiar course of events. This suggests a very wide range of phenomena, including things normally considered either "impossible" or otherwise explicable entirely by ordinary "chance" or "random" effects, without any underlying spiritual meaning. It has no connection with the very particular set of "miracles" ( $m u$ ' $g z i z \bar{t} t)$ seen as demonstrating the proof of a particular prophet's mission. 


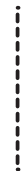

\section{THE HUMAN SOUL'S "DYINGS" AND REAWAKENING:}

The following short passage ${ }^{17}$ is a clear introduction to the many kinds of "dying" and corresponding awakenings that flow through all of Ibn 'Arabỉ's discussion of the different ways that we begin to "wake up" to the deeper meanings and intentions behind the shadowscreen of the events and dramas of life in this "lower" world $($ duny $\bar{a})$ :

The setting of the Sun is the dying of the soul, so look at

the Light He has inserted in the dust (of Adam, at 35:11, etc.):

For that spirit-breath is God's Spirit in us, so with His inbreathing $(15: 29$, etc.) begins Its returning

Until that appointed time,$^{18}$ which He races beyond;

for He hastens on in both the returning and the going out.

He explained: The soul is like the sun. It shines forth from the Spirit that is linked to God in His "inbreathing" (of "My Spirit/Breath," rūhī, into Adam, at 15:29). And (the sun) sets in this (earthly) plane of being $\left(n a s^{\prime} a\right)$ and is darkened by the atmosphere, so that it is said: "Night comes, and the sun runs away." So the death of the soul is its existence in this (lowly) plane of being - yet the very life of this plane of being is through the existence of the soul/ Spirit/"sun" within it.

Now this sun necessarily rises up after its setting: for that is the Day [when there come some of the Signs of your Lord,] when the faith a soul had is of no use, nor that in which it had faith before, nor the good it acquired through its faith (6:158).... For the rising of (this sun of the Spirit) from its setting is the Life of the soul and the dying of this (earthly) plane of being.

So in the soul's dying is its (eternal) life, and in its (earthly) living is its death. For its condition is interpenetrated (with living and dying) because it is (shaped) according to the form of

17 From the same page of the Futühät (IV, 434), immediately before the previous short translated section.

18 This key term is mentioned many times in the Qur'an, in reference to the "destined time" or end of mortal human lives or sometimes of entire communities and peoples. Here this word appears to allude to the specific context of verse 39:42, which underlies many of Ibn 'Arabï's following discussions of the soul's destination in both death and sleeping: God receives the souls when they die, and those that do not die during their sleep. Then He takes those whose dying has been decreed, and He sends back the others (to their awakening) until an appointed time...

In the rest of this poetic line, Ibn 'Arabī contrasts that familiar subjective "time" of earthly human experience with the Spirit's perpetual "ever-renewed creation" (tağdìd al-halq) of all manifest existence at every instant, one of the cosmological and spiritual/phenomenological foundations of his worldview. (See further illustrations and related passages in the references cited at notes 6, 7, and 13 above.) 
the One Who gives it Being... ${ }^{19}$ For since He is influenced (in His never-ending creative Self-manifestations) by the different planes of being, ${ }^{20} \mathrm{He}$ is also influenced (i.e., mahkum, as well as the wisely governing and determining Ruler, Hākim and Hakim). So in it (i.e., in His creation) is what is in Him. ${ }^{21}$

\section{TWO AWAKENINGS: THE "LESSER" AND "GREATER" DYING ${ }^{22}$}

In the course of the Futūhăt as a whole, Ibn 'Arabī follows many earlier Sufi teachers and writers in discussing a wide range of types of recurrent spiritual experiences of awakening in technical, symbolic terms alluding to different kinds of "dying." 23 Needless to say, both cinema and literature more widely provide an immense gamut of memorable illustrations of the different types of spiritual phenomena and transformations Ibn 'Arabī is so frequently discussing in this familiar symbolic language of death and rebirth.

And whoever is blind in this (life), then he is blind in the other world, and even more astray in the Path (17:72). He explained: Just as you are today, so shall you be tomorrow. So strive to be here among those who envision things as they really are!

An indication pointing to this is that those whom God created blind from birth do not see (visually) when they dream, ${ }^{24}$ just as they don't see in the waking state.... For sleep is a little

19 On God as the "Shaper" (musawwir) of all creation, see n. 11 above. This sentence alludes to the famous hadith stating that "Adam was created according to the form of the All-Compassionate ('ala șürat al-Rahmānn)" Since the Qur'an elsewhere stresses the equivalence between the divine Name al-Rahmān and the comprehensive Name "God" (Allāh), Ibn 'Arabī here is expressing the underlying ontological basis for the uniquely comprehensive nature of the Adamic, human being (n. 21 below).

20 Mawātin, or ontological "homelands," a term loosely equivalent to naš' $a$ and hadara already used above to refer to levels of being and existence. Ibn 'Arabī goes on to explain very briefly here his foundational understanding - most famously elaborated in his opening chapter on Adam in his Fusūs al-hikam - that God as manifested in creation necessarily takes on all the positions of the Highest and the most low.

21 Fìhi mā finh: This multifaceted Arabic expression can also simply allude to the presence of the infinite divine Names expressed through all the stages and planes of manifestation and creation. But Ibn 'Arabī's frequently repeated emphasis, further highlighted here, on the divine Presences throughout even what we often conceive as the "lowly" dimensions of human life and experience is in fact inseparable from his guiding conception of the full perfection and completion (kama $\bar{l}$ ) of our uniquely Adamic/human potential to know and recognize "all the divine Names," archetypally dramatized in the telling encounter between Adam and the angels at 2:31 and elsewhere in the Qur'an.

22 From chapter 559, vol. IV, pages 423-424.

23 See our selection of translated passages on this particular theme often including vividly memorable anecdotes--included in section III ("Lesser and Greater Resurrection") of Les Illuminations de La Mecque, republished as The Meccan Revelations, vol. I (New York, Pir Press, 2002).

24 I.e., they do dream, but employing their other, unimpaired senses. (Modern sources appear to be 


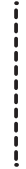

death, since it is just like death in respect to that plane of being ${ }^{25}$ to which the sleeper is transported - which is precisely that to which the dead person is likewise transported. ${ }^{26}$ And waking up after sleep is like the "raising up" (bat: of the soul) after death.

And whoever is blind in this (life), then he is blind in the other world, and even more astray in the Path -i.e., even more blind. ...Yet (in the other world) the veil is necessarily lifted away so that he sees. ${ }^{27}$ So the dying person only dies seeing and recognizing what it is that he is (already) seeing. Hence he is raised up according to that — so understand!

\section{SEEING THROUGH THE DREAM: SLEEPWALKING, OR REGOGNIZING THEOPHANY? ${ }^{28}$}

The following short summary beautifully expresses the essential, eternally problematic interplay between the artist's means and intentions, on the one hand, and the wider spectrum of spiritual aptitudes and receptivities (istic $d \bar{a} d$ ) among life's many audiences. In particular, Ibn 'Arabī's condensed account here of these two radically opposed responses to life's tests and the promptings of Grace beautifully evokes the spiritually positive and negative roles of each soul's particular "passionate love" and attachment ${ }^{29}$ in either motivating us to realization and self-discovery, or in binding us ever decper to life's many familiar "sleepwalking" states and routines. This recurrent challenge - and one has only to observe the differing responses of a sensitive audience to a powerful but unfamiliar film or other

somewhat uncertain as to the universal validity of this phenomenon; but that question is not relevant in itself to the argument about dreams and posthumous experiences of the soul that Ibn 'Arabì is actually developing here.)

25 Hadara or divine "Presence" is one of several related technical terms (see n. 20 above) that Ibn 'Arabì uses to refer to different ontological levels, domains or fields of the creative divine Self-manifestation. (This basic terminology and related metaphysical distinctions were rapidly expanded and developed by Ibn 'Arabī's immediate successors and many later interpreters, in their still ongoing encounter with the Avicennan traditions of Aristotelian philosophy.)

26 This entire passage is based on the Qur'anic verse 39:42, which underlies many of Ibn 'Arabî's following discussions of the soul's destination in both death and sleeping: God receives the souls when they die, and those that do not die during their sleep. Then He takes those whose dying has been decreed, and He sends back the others (to their awakening) until an appointed time...

27 Alluding to a famous verse recounting God's addressing a wrongdoer at the last Day: "You used to be in heedlessness of this. But we have lifted your veil from you, so Today your vision is sharp." (50:22). As with the corresponding symbol of "blindness" in the Qur'an, the particular Arabic root used to speak of "vision" in this verse and the wider passage $(b-s-r)$ refers more broadly to both physical and spiritual "insight" and perception, much more extensively than just the physical sense of sight.

28 From volume IV, p. 402, referring to the inner meaning of chapter 372.

29 Ta aš $^{\prime} u q$, from the Arabic term 'išh $q$, which later becomes the most common expression for the divine Love (and indeed for God more generally) in classical Persian poetry and other Islamicate literatures following Persian models. 
artistic performance to discover vividly familiar illustrations of what Ibn 'Arabī is describing here - points directly to two fundamental areas of his work as a writer and teacher. The first is his highly influential shorter treatises on practical spiritual disciplines and guidance, which were often the most frequently copied and studied writings over subsequent centuries. ${ }^{30}$ And the second is his much more unique and far-reaching concentration in the Futūhat on the phenomenology of walayya, carefully surveying all the innumerable expressions of God's guidance and providence through the ongoing transforming influences of "God's Friends" (awliy $\vec{a}^{\prime}$ Alla $h$ ) and vast hierarchy of spiritual guides and intermediaries in this world and beyond: the subject and unifying perspective which is the most prominent and consistent focus of the entire Meccan Illuminations.

He explained: Every divine Name (quality, attribute) has a particular theophany/Selfmanifestation (tağalli), so that the heart must necessarily bow down to that. So the heart never stops turning over ${ }^{31}$ from one bowing down to another. And that inner "constant overturning" (taqallub) is why the heart of the spiritual Knower is called a "heart" (qalb) unlike the hearts of the ordinary people-i.e., because of the different fluctuations of what occurs to it from the states of this lower world. Because for the Knower, those shifting states themselves are the divine Names.

So look and reflect on the distance between these two levels, how this person rises up (spiritually) through precisely what brings that other one down. That is the manifest Loss! (22:11;39:15).

And he said: What transpires (in these contrasting states of deepening spiritual insight or heedlessness) only happens through the passionate love of each soul for the condition it is in. Each group is rejoicing in what is with them (23:53; 30:32). For if it became clear to each group what it had (or: what was in its favor) and what the other group had, then whoever ought to rejoice would rejoice - while whoever ought to be saddened would be saddened. And he said (of this latter, "sleepwalking" group): if they were to leave the abode (of this world and the next) for that state in which they were at the very beginning, when they said "Yes indeed, [we have borne witness]. "32 — then they would be happy and blessed.

30 Several of the most influential of those practical treatises are translated and included in our forthcoming volume Approaching Ibn 'Arabī... (n. 7 above).

31 Taqallaba. Simply citing some of the many meanings of this verb suggests some of the ways this phenomenon is often elicited by great works of music, drama, cinema, and so on: (constantly) fluctuate, alter, be knocked over, be overturned, be upset, be transformed, transmuted, converted, etc.

32 Referring to the Qur'anic account of the primordial covenant of all human souls with their Creator: And when your Lord brought out the children of Adam from their backs, their descendants, and caused them to bear witness against themselves, (saying) "Am I not your Lord?" They said: "Yes indeed, we have borne witness!"... (7:172). 


\section{TWO KINDS OF "BEWILDERMENT": THE LIMITATIONS OF INTELLEGT AND ILLUMINATION}

Every religious tradition, large and small, has been profoundly marked by the spiritually transforming role of artistic and ritual means functioning as effective catalysts in supporting and provoking those spiritually transforming experiences and moments of sudden illumination that Ibn 'Arabī often speaks of as crucial "theophanies" or divine "Selfmanifestations" (tağalliya $t)$. One does not have to be a professional critic to recognize the fundamental distinction the Šayh develops here between the limited power and influence of our conceptual reasoning and the often transforming "bewilderment" (hayra) provoked by each unforgettable instance of direct spiritual awakening and transformed vision. Each reader - and viewer - should be able to provide multiple examples of the kinds of intuition, illumination, and deeper transformation that Ibn 'Arabì is evoking here. At the same time, his clear mention of the (radically different) inherent limitations of both paths to deeper understanding and awareness of God pointedly suggests recurrent dilemmas of communication, proper interpretation, and effective application of those insights which still remain centrally unavoidable both for more recent artists, in all media, and their many audiences alike.

The contemporary spread of interest in Ibn 'Arabî's teachings to much wider global audiences, far beyond (in so many different ways!) the scholastic theological circles and Sufi groups in which he was primarily studied for centuries, should soon lead to a deeper appreciation and more productive focus on the still largely unexplored creative and affective dimensions - both artistic and pedagogical - of his work as a lastingly influential poet, artist, and communicator.

Chapter 542, concerning the inner knowing of the state of the spiritual Pole whose station is And whoever is blind in this (life), then he is blind in the other world, and even more astray in the Path $(17: 72)^{33}$

33 Vol. IV, p. 185. Chapter 542 is part of the long concluding sixth division of the Futühät (Fassl VI, chapters 462-558 ; volume IV, pp. 74-325) devoted to "the spiritual mottocs (Hïğ̌̌ziāt: key Qur'anic phrases and litanies of prayer and spiritual "remembrance") of the Muhammadan Poles and their spiritual stations." In introducing this rich treasury of spiritual wisdom, Ibn 'Arabī explains the particular phenomenological focus of these final 96 chapters as follows:

"So let's begin with the spiritual Poles and the spiritual "mottoes" they manifest. I mean by that those distinguishing indicators such that whoever acts according to them finds/experiences what (those "Poles") found and witnesses what they witnessed. Because I constructed this book of mine- or rather God constructed it, not I! - in order to help and fully inform the people. For all of it is a spiritual illumination (fath: a sudden spiritual "opening") from God". 
[Surely their vision is not blind, but] It is only the hearts in the chests that are

blind, I (the hearts) that are contained within their chests. ${ }^{34}$

Then this judgment (of "blindness") is for whoever has proceeded beyond that arriving through which things come (from God).

But the one who is proceeding from Him with Him:

how can he who has the eye/essence of (divine) Manifestation be blind! $?^{35}$

God said: ... But it is the hearts in the chests that are blind (22:46) in two different senses. One of those senses is through restriction, the other through returning (to Him). ${ }^{36}$

Now you must know that this "blindness" (in knowing God) is bewilderment, ${ }^{37}$ and the most immeasurable bewilderment is in knowing God.

And we come to know God in two ways. The first way is through discursive thinking. And the person following this way - if his reflection reaches its goal - is in bewilderment until his death. For there is no "evidence" (dalī $)$ pointing (to God) that is not also implicated with doubt for that person, because of the immense extent of the world of (divine) Imagining, ${ }^{38}$ since the power of discursive thinking only operates on that plane of (cosmic) Imagination, either through what it acquires through the faculties of sensation or through what is conceptualized by its conceptual power.

34 This opening line alludes to the full verse only partially quoted here (22:46): Have they not traveled through the earth, for they have hearts with which to understand and ears with which to hear!? Surely their vision is not blind, but the hearts in the chests that are blind... Here the "chest" (sadr) seems to symbolize all that can obscure the spiritual perceptions of the heart (qalb). But more often in the Qur'an it serves as a virtual synonym for the heart. See the overview of the Šayh's complex understanding of the sadr in our study "Opening the Heart: Ibn 'Arabī on Suffering, Compassion and Atonement," in Journal of the Muhyiddin Ibn Arabi Society, vol.51 (2012), pp. 27-56.

35 This final line of poetry describes the fully enlightened state of the "complete" or "perfected" soul (kāmil) and the cosmic Logos or "Perfect Human Being" (insān kāmil) discussed near the end of this chapter.

36 It may be helpful to clarify at the start that throughout this chapter Ibn 'Arabī is ironically-indeed almost humorously — using and understanding the Qur'anic expression for "blindness" (as well as that for "wandering" or "going astray") in two radically opposed ways, referring critically to the inherent limitations of the human intellect in this world, and much more positively to the soul's receptivity to theophanies and divine "unveiling" already in this world and even more so in the next.

37 Ibn 'Arabī most often uses the term "bewilderment" (hayra) in an extremely positive sense, referring to the complete openness and surrender to the ever-renewed divine Presences and theophanies, at every instant, which he presents as typifying the state of Muhammad.

38 See the key passages on the divine "Imagining" (hay $\bar{l}$ ) in the translations from chapter 63 (on the Barzah) earlier in this essay. 


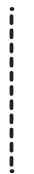

So whether the person following this reasoning is blind-I mean "bewildered"-in this lower world or has died, either way the human being only dies according to the state in which he has lived. And such a person has only lived in bewilderment, so he comes to the next world with that (intellectual) bewilderment. But if that person experiences (further spiritual) "unveiling" there (in the next world), then he is increased in bewilderment through the differing forms that he experiences ${ }^{39}$ so that he is even more "astray" than he was in this lower world. For in this lower world, if something was unveiled to him, he was used to asking or expecting for that bewilderment to be removed from him. ${ }^{40}$

As for the second way of coming to know God, that is by knowing through His Selfmanifestation/theophany (tağalli) - and God never manifests Himself in the (same) form a second time. For the master of this knowing of God is bewildered through the differences in the forms of His Self-manifestation (in this world), just as the other person is bewildered (by His unveilings) in the next world. So what that first person experiences in the other world is what this other one (relying on their realization of theophany/divine Self-manifestations) experiences already in this lower world.

And as for that "enlightened insight" (basira, at 12:108) which is the state of the one calling upon God with clear insight, ${ }^{41}$ that only concerns whatever he is calling for - and that calling only involves the path to true happiness, not the way to knowing (God). But if such a person (possessing that rare insight) also calls for knowing (of God), he is only calling for more bewilderment, following the clear insight that there is nothing there but bewilderment concerning God, since this matter is immeasurable and what is being called for cannot be either restricted or controlled! So that person really has nothing at his individual disposal, and he can only rely on what he sees in each Self-manifestation.

39 Based on a range of Qur'anic verses and hadith, Ibn 'Arabī explains at a number of points in the Futühät that the next world (or at least the domain of the "Gardens") is marked by a constant transformation of states and forms. See our translations of a few of those passagees among the eschatological selections cited at n. 23 above.

40 The humorously apt psychological observation here is developed at great length in chapter 167 of the Futūhāt, which recounts the tale of the spiritual ascension (mi'rāg $)$ of a "person of faith" (mu'min: a very high spiritual state in Ibn 'Arabī's usage), following in the footsteps of the Prophet, who is also accompanied by an Avicennan, rationalist philosopher: this highly "intellectual" companion remains throughout in a sad and often comical state of blind obliviousness to most of what is being discovered by and revealed to his more spiritually receptive companion. See the translation of this chapter by S. Ruspoli, L'Alchimie du Bonheur Parfait, Paris, Berg, 1981.

41 The allusion here is to the Qur'an 12:108: Say: This is my Path - I call upon God with clear spiritual insight (basīira). 
Now the perfected soul (al-kämil) sees the ongoing transformation of the forms (of all creation) within the One Essential Being (al-'ayn al-wāhida). ${ }^{42}$ For He (the Manifested divine) is like the chameleon (in that the infinite changing forms of creation resemble the changing colors of the chameleon): so whoever doesn't recognize and know God in the way that we recognize the chameleon (i.e., along with and despite all his changing colors) does not have a stable and firm basis and a sound footing for affirming the Essential Being (al-'ayn).

Hence those familiar with the theophanies/Self-manifestations have an early awareness in their knowing of the other world. So in this world they are "blinder" and "more astray in the Path" than the masters of conceptual reflection, because they are not seeking any further knowing of God nor are they hungering for that. And this allusion is sufficient for those who (can) understand.

And God speaks the Truth and He guides rightly in the Path (33:4) - for what can be said about this formula of remembrance (i.e., verse 17:72 in this chapter title) is far-reaching.

\section{IBN 'ARABĪ'S GONGLUDING SUPPLICATION: "WE ARE ONLY A STORY"}

The concluding section of Ibn 'Arabī's Meccan Illuminations, ${ }^{43}$ begins with the final line of his poetry (among the thousands of poetic lines included throughout that work), a simple exhortation that aptly sums up the complex metaphysics and theology of that work as well as its most practical import:

People are only a story, all of them:

So be the best story they hear! $!^{44}$

The final chapter 560 that concludes here-devoted to "Wise Advice From Which Both the Seeking (beginning) Spiritual Voyager and the One Who Has Arrived Can Benefit" (its title, IV, 444) - is often reprinted in Arabic today as a long separate volume (which would require several volumes to translate into any European language). However, it has

42 This short sentence (echoing the final line of the opening poem, at n. 35) clearly alludes to what many earlier generations of classical Sufi writers and teachers had repeatedly described as the culminating stage of spiritual illumination and perfection, where the purified and surrendered soul-having reached a kind of "dissolution" of the self into its divine Ground and Source (fana $\bar{a} f \bar{\imath}$ Alläh) - then moves on to an even deeper perception of the "abiding" and emergence of all things within that divine Reality (the station of baqā'ba'd al-fan $\bar{a}$ ). As Ibn 'Arabī suggests in the final line of this chapter below, much of the Futühat is actually devoted to the issues and contrasting states and ways of life so briefly suggested here.

43 Hätimat al-kitāb, at the very end of the long final chapter 560, vol. IV, pp. 551-552. All the translated selections below are drawn from this final "Conclusion of the Book."

44 Innamā-n-nāsu hadītun kullu-hum, fa-l-takun hayru hadītin yasma u/yusmáu. (vol. IV, p. 551). 


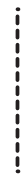

not yet received from other scholars and translators the attention it surely deserves as a comprehensive practical expression, and highly effective popular communication, of all of the spiritual teachings more fully and theoretically elaborated throughout this vast work. Its much wider contemporary significance is also emphasized by Ibn 'Arabî's conscious effort here to draw on a wide spectrum of teachers and writings explicitly taken from several wider religious and wisdom traditions, intentionally highlighting the deeper human universality of everything that he had almost always expressed elsewhere in the Futühāt through the classic scriptural sources and interpreters of the Islamic tradition.

His own concluding advice (wasiyya) here is expressed in the very appropriate devotional form of a comprehensive petitionary prayer $\left(d u^{c} \bar{a}\right)$ that touches on the proper inner spiritual attitude and awareness we should bring to every situation and time of the daily cycle of life. In light of our particular subject here, it is surely noteworthy that most of this initial personal prayer is actually focused on one's proper mindset while going to sleep, awakening, and readying oneself for bed, thoroughly integrating all of the themes of dreaming, death and reawakening that we have just encountered in their earlier, more theoretical expressions:

And it is said upon sleeping, after the person has taken to bed: "O my God, I surrender my soul to You. I turn my attention entirely to You. I entrust my affair to You. I take shelter in You, in awe of You and in hope of You. There is no refuge and no deliverance from You except through You. I have faith in Your Book that You have sent down, and in Your prophet whom You sent. O my God, I live in Your Name, and I die in Your Name. Glory be to You, my Lord: I hand myself over to You and dedicate myself to You. If You should take my soul, then pardon her. And if You should send her (somewhere), then protect her as You safeguard and preserve your righteous servants $(66: 10)$."

And it is said upon awakening from sleep: "Praise be to God Who has brought us to life after He caused us to die (while sleeping) - and to Him is the resurrection!"

And when you want to sleep, you should ready yourself to meet your Lord and you should love sleep because your meeting your Lord is in it (in dreams) - just as you (should) love dying because meeting your Lord is in that. For (in the words of the famous hadith) "whoever loves to meet his Lord, God loves to meet him; and whoever detests meeting his Lord, God detests meeting him." And God receives the souls when they die, and those that do not die during their sleep. Then He takes those 
whose dying has been decreed, and He sends back the others (to awakening) until an appointed time... (39:42).

So sleep is a little death, and the person who is transferred to it after dying is (the same one) who is transferred to it in sleep: it is a single plane (of divine Presence: hadra), which is the barzah, and the form is one (in either case). Waking up is like the uprising (of each soul) on the Day of Rising. God only established sleep in this lower world and what we see in dreams while sleeping for the people of this lower world, and He established awakening after that. He made all of that as a likeness for dying, and what we witness in it (as a likeness) for dreaming, and the arising (as a likeness) for awakening. So waking up from bed is just like arising from the graves....

Soon after this, while continuing with the same long prayer, Ibn 'Arabī suddenly interrupts it abruptly to provide the striking and significant clarification that:

"I heard this supplication from the Messenger of God (may God's blessings and peace be upon Him), in a dream that he called me to, after the completion of a reading of the book of the Sahnh (hadith collection) of Buhārī, in the year 599 (AH), in the city of Mecca between the two gates ...."

Then, before eventually continuing this prayer, Ibn 'Arabī gives a long description of the companion from Tlemcen who was giving that reading of Buhārī (and from whom he had earlier heard a recitation of Ġazālī's immense Ihya $)$. This detailed contextual background is then followed by a much longer description of his ensuing conversation with the Prophet about a controversial issue of divorce procedure, followed by his recounting of an even more dramatic dream encounter between the Prophet (and Iblis) that he had witnessed later in the same year. Like the countless other autobiographical, firsthand anecdotes that so often punctuate all of these Futūhāt (and which are even more prominent in many of the Šayh's other writings) these two detailed dream-encounters, at such a critical concluding moment in the entire book, are surely meant to provide a memorable concrete illustration of the providential ways that we are all meant to learn from, and pass through and beyond, this dreamlike stage of earthly life.

As Ibn 'Arabī succinctly puts that point at the very beginning of this concluding supplication:

"The people are only a story, all of them:

So be the best story they hear!" 